\title{
ICE LITHOLOGIES AND STRUCTURE OF ICE ISLAND ARLIS II*
}

\author{
By David D. SmIrh ${ }^{\dagger}$ \\ (Coastal Studies Institute, Louisiana State University, Baton Rouge 3, Louisiana, U.S.A.)
}

\begin{abstract}
Ice island ARLIS II, which is adrift in the Arctic Ocean, is a $1 \cdot 3 \mathrm{~km}$. wide and $3 \cdot 8 \mathrm{~km}$. long fragment of shelf ice $12-25 \mathrm{~m}$. thick, which preserves several structural features heretofore undescribed in ice. The island is composed of an irregular central block of foliated, locally debris-rich, grey glacial ice bordered in part by extensive areas of stratified bluish sea ice. The central block contains a series of narrow, elongate, sub-parallel dike-like septa of massive fresh-water ice and a large tongue-like body of tightly folded, coarse banded ice. Both the septa and the tongue cut across the foliation and debris zones of the grey ice.

The margins of the central block are penetrated by a series of elongate, crudely wedge-shaped re-entrants occupied by salients of bluish sea ice. Two broad, arch-like plunging anticlines deform the stratified sea ice along one margin of the block.

The foliation and debris zones in the glacial ice are relict features inherited from the source glacier. The septa formed as crevasse and basal fracture fills. Salients represent fills formed in the irregular re-entrants along the margins of the glacial ice mass. The tongue of tightly folded, banded ice represents an earlier generation salient deformed by compressive forces as the fill built up. The broad anticlines are apparently the result of warping in response to differential ablation but the small, tight plunging folds on their noses and
limbs are probably the result of compressive forces.
\end{abstract}

RÉsumé. L'île de glace ARLIS II, à la dérive dans l'océan Arctique est un fragment de glace de shelf dont les dimensions sont les suivantes: longueur $3,8 \mathrm{~km}$, largeur $1,3 \mathrm{~km}$, épaisseur 12 à 25 mètres. L'ensemble est parsemé de bosses de 10 à 12 mètres de haut couvertes de débris. Cette île est formée par un bloc central irrégulier de glace grise de glacier, feuilletée et localement riche en débris, bordée partiellement par de grandes zones de glace marine bleuâtre et stratifiée. Le bloc central comprend une série de septa de glace d'eau douce et une large langue de glace grossière qui s'enchevêtrent avec les zones de foliations et de débris de la glace grise. Les partitions sont étroites, allongées (presque parallèles) et semblables à des filons.

Le pourtour de ce bloc central est découpé selon des indentations allongées grossièrement en angle aigu et remplies par des saillies de glace bleuâtre d'origine marine. Cette glace marine est déformée sur l'un des bords du bloc par les versants plongéants de deux larges anticlinaux.

Les zones de foliations et de débris de la glace proviennent du glacier dont cette île s'est détachée. Les septa sont le résultat du remplissage de crevasses et fractures de base. Les parties saillantes de la bordure qui s'enfoncent dans le bloc central sont le résultat du remplissage des indentations de ce bloc. La langue de glace striée et fortement plissée résulte de l'action combinée du remplissage antérieur d'une indentation et de forces de compression. Les larges anticlinaux sont apparemment la conséquence de plissements dûs à des ablations différentielles, mais leurs versants abrupts et pincés aux extrémités sont probablement dûs à des forces de compression.

Zusammenfassung. Die im nördlichen Eismeer schwimmende Eisinsel ARLIS II ist ein $\mathrm{I}, 3 \mathrm{~km}$ breites, $3,8 \mathrm{~km}$ langes und $12-25 \mathrm{~m}$ dickes Eisschelffragment; mit Steinschut bedeckte, $10-12 \mathrm{~m}$ hohe Hügel übersäen die Eisinsel. Diese besteht aus einem unregelmässigen inneren Block von örtlich geschiefertem steinschuttreichem grauem Gletschereis und ist teilweise umgrenzt von ausgedehnten Flächen bläulichen Meereises. Der innere Block enthält eine Anzahl von schmalen, länglichen, subparallelen Gesteinsaderähnlichen Septa aus massivem Süsswassereis und eine ziemlich grosse Zunge von eng-zusammengefaltetem, grobem gebändertem Eis. Sowohl die Septa wie auch die Zunge kreuzen die Schieferungs und Steinschutt-
zonen im Graueis.

Die Ränder des inneren Blockes sind durchsetzt von einer Reihe spitzer, keilförmiger Einschnitte, welche mit Vorsprüngen aus bläulichem Meereis ausgefüllt sind. Zwei breite, bogenähnliche, untertauchende Antiklinale verändern das geschichtete Meereis an einer Seite des Blockes.

Schieferung und Steinschuttzonen im Gletschereis sind Relikte des Ursprungsgletschers. Die Septa bildeten sich als Gletscherspalten- und basale Bruchfüllung. Die Meereisvorsprünge entstanden als Ausfüllungen in den unregelmässigen Einschnitten entlang den Rändern der Gletschereismasse. Die Zunge des enggefalteten, gebänderten Eises repräsentiert den Vorsprung einer früheren Periode, welche durch auf die Ausfüllung einwirkende, zusammenpressende Kräfte verändert wurde. Die breiten Antiklinalen sind anscheinend das Resultat von Auffaltungen unter dem Einfluss von differentieller Ablation, aber die kleinen, engabfallenden Falten auf ihren Nasen und Gliedern sind wahrscheinlich das Resultat von zusammenpres-
senden Kräften.

* Based on research carried out under the auspices of the Arctic Research Laboratory and sponsored by the Geography Branch, Office of Naval Research, Contract N onr 1575 (o3); Task Order NR 388 oo2. U.S.A.

$\dagger$ Present address: Ocean Science and Engineering, Inc., DuPont Circle Building, Washington 6, D.C., 


\section{INTRODUCTION}

In late May I96I, personnel of the Arctic Research Laboratory located a small ice island about $200 \mathrm{~km}$. north of Point Barrow, Alaska, and subsequently established a scientific station ARLIS II on the island (LeShack, I96I). The writer, assisted by R. Lynn Schraeder, Department of Geology, University of Alaska, spent the three summer months of I 96 I carrying out a detailed geologic-glaciologic investigation of the island.

About eighty ice islands are now known (Koenig and others, I952; Montgomery, 1952; Crary, 1960, p. 48), most of which occur in or near the Canadian Arctic Archipelago. Hattersley-Smith (in Koenig and others (1952, p. 95-100)) proposed that the islands result from fragmentation of the ice shelf of Ellesmere Island. Field work on ice island $\mathrm{T}-3$ by Crary and others (1952), Crary (1958) and Marshall (1960); and on the ice shelf of Ellesmere Island by Hattersley-Smith and others (1955), Hattersley-Smith (1957[a], I957[b]), Crary (1958) and Marshall (1955, 1960) confirmed that the ice shelf is the source of $\mathrm{T}-3$ and the other ice islands on the basis of similarity in ice types, ice structures and surface characteristics. Other papers concerning the characteristics of the ice islands and the problem of their origin include Helk and Dunbar (1953), Debenham (1954), Dibner (1955), Zubov (1955) and Burkhanov (1957). (See also the compilations of detailed papers on T-3 edited by Bushnell ( $1959-60)$.)

It appears definite that ice island ARLIS II is the same island used as a survey station by a Canadian Polar Continental Shelf Project party under Dr. E. F. Roots, in April 1959, when it was about $25 \mathrm{~km}$. north-west of Cape Isachsen, Ellef Ringnes Island (Hattersley-Smith, I $96 \mathrm{I}$ ). On the basis of comparison of ARLIS II rock types with the descriptions of bedrock along the north-west Ellesmere Island coast, the source of the island is probably the Cape Alfred Ernest-Alert Point-Phillips Inlet area. Roots reached similar conclusions (HattersleySmith, I96I).

Because suitable air photographic coverage of ARLIS II could not be obtained, geologic mapping was carried out by standard plane-table methods using scales of I :200 and I $: 300$. Contacts between ice types were generally easily visible and in most areas dips on contacts and planar structures were readily measured. As much as $2 \mathrm{~m}$. of local relief, principally

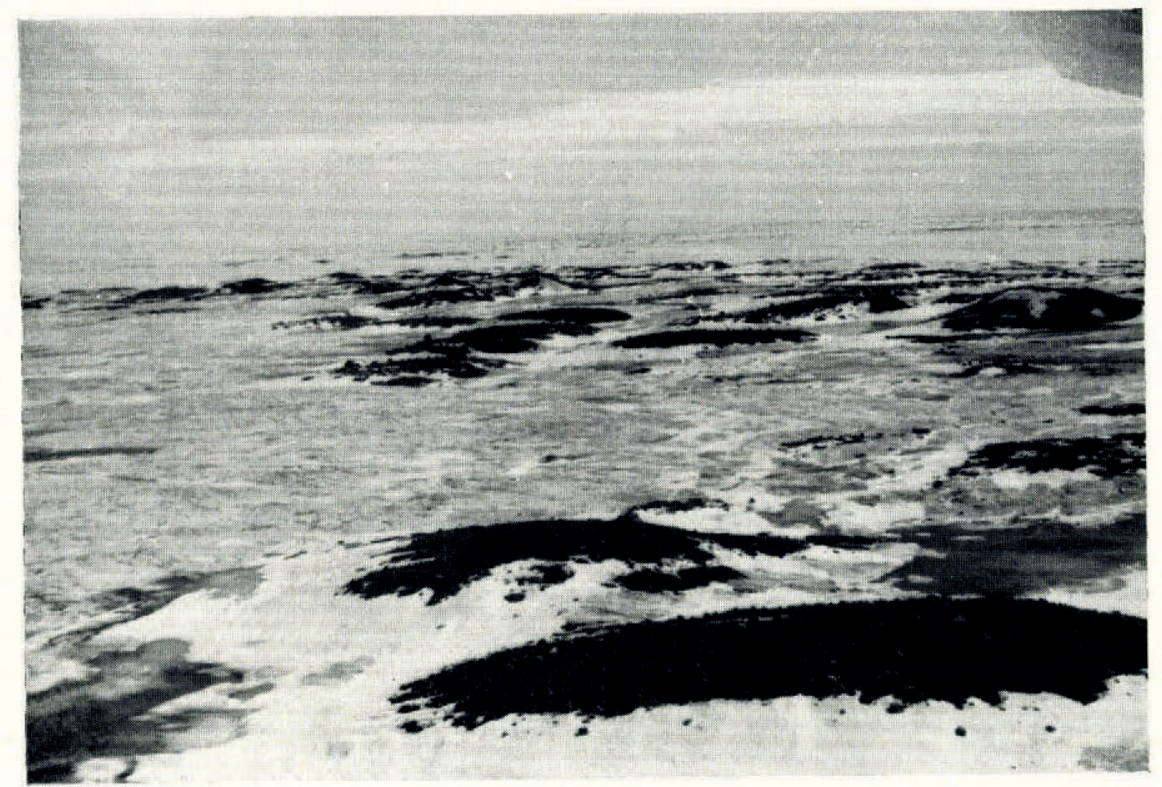

Fig. I. Air view of ARLIS II and "Halleluiah Hills". Hills in foreground 8-IO m. high. See Figure 10 for location 
along stream valleys, facilitated an understanding of three-dimensional relations. Along critical contacts, a limited amount of chain-saw excavation and core drilling was carried out. Inasmuch as the island rotates, a reference azimuth, termed "ARLIS North", was established. All compass directions in this paper given for the island proper refer to this azimuth.

\section{Description OF THE IsLAND}

Ice island ARLIS II (Fig. I), when initially occupied in May I961, was a crudely rectangular mass about $6.5 \mathrm{~km}$. long and $3.0 \mathrm{~km}$. wide, ranging in thickness from about I 2 to $25 \mathrm{~m}$. (Kutschale, unpublished). In mid-July I96 I an extensive system of fractures developed along the east edge of the island. About two weeks later a fracture extended across the short axis of the island severing it into two roughly equal units. The southern unit (Fig. 2), on which the station is located, was about $3.8 \mathrm{~km}$. long and varied in width from $\mathrm{I} \cdot 3$ to $3.0 \mathrm{~km}$. This paper is based almost exclusively on the structural relations studied and mapped on the south island.

ARLIS II is atypical with respect to most ice islands presently known in that its surface, which averages about $2 \mathrm{~m}$. above sea-level, is marked by numerous prominent rock-covered,

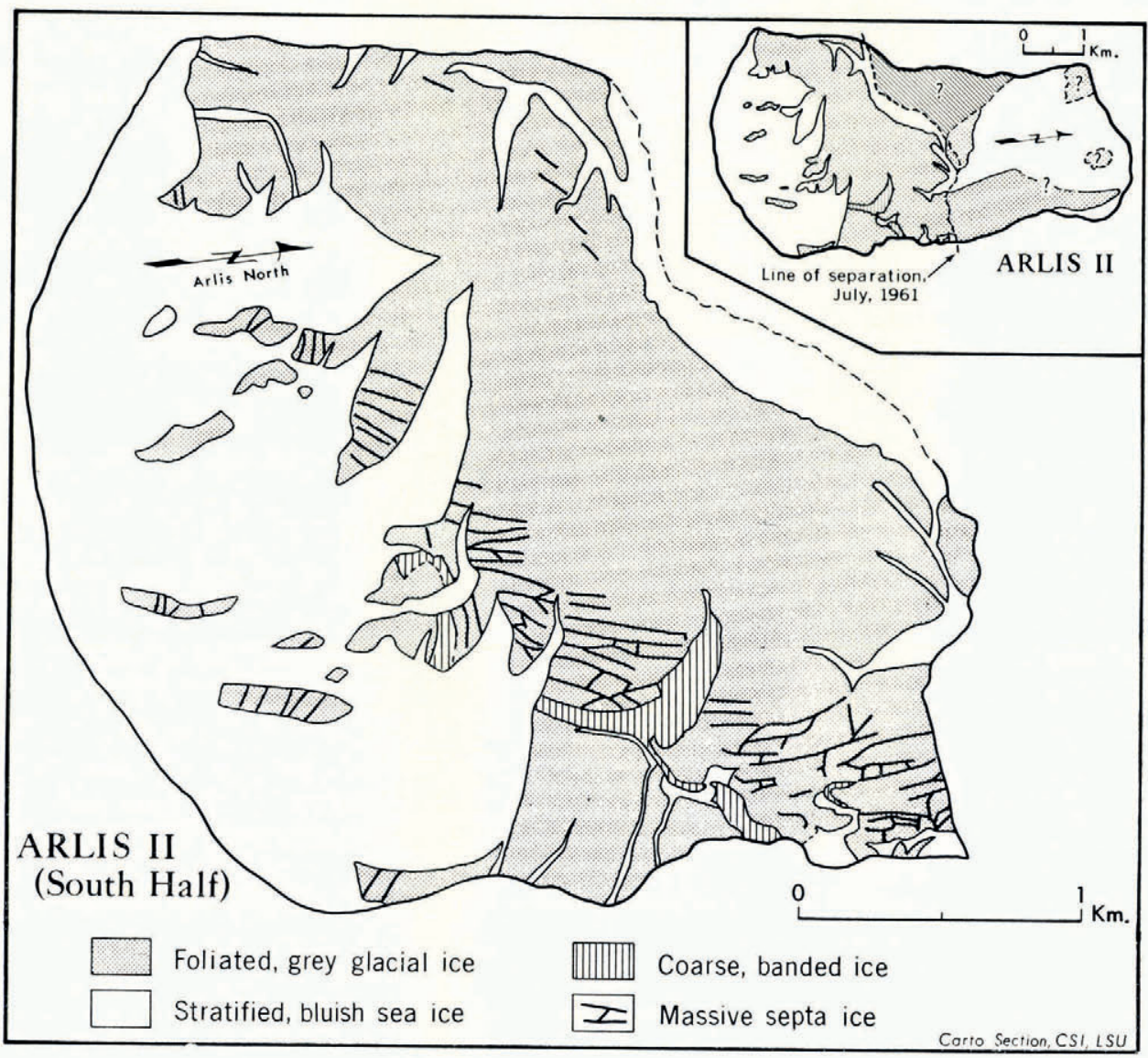

Fig. 2. Generalized ice lithology map. Configuration of the island prior to July $196 I$ sub-division is shown in the upper right. Diagonal pattern is area of fragmentation 
ice-cored hills, some of which attain heights of 10 to $12 \mathrm{~m}$. (but see Koenig and others (1952, fig. 17) and Debenham (1954, fig. 4)). These hills occur in three elongate series trending approximately parallel to the long axis of the island and owe their topographic prominence to the protective effect of the debris cover. The southern third of ARLIS II is marked by a series of large, crudely parallel estuarine lakes, but such lakes are absent elsewhere.

\section{ICE Lithologies}

ARLIS II consists primarily of a central mass of foliated, grey glacial ice bordered in part by extensive areas of stratified, bluish sea ice (Fig. 2). Stratigraphically, the relations of the two units are inverted, i.e. the younger stratified sea ice underlies the older grey ice at a number of localities. Other lithologies important locally are a coarse, banded ice, which occurs as a large tongue-like body near the eastern edge of the island, and the massive ice comprising the dike-like septa near the "Obelisk Hills". In addition, minor but petrologically interesting variants of each major lithology are present.

The principal identifying criteria of ice units, for field mapping purposes, were texture, color and type of planar structure present. In addition, such features as bubble content, micro-relief and the nature of the weathering products were commonly diagnostic. The following summary of lithologic characteristics is based primarily on examination of hand specimens in the field by the writer, subsequently supported by microscopic study in the laboratory by Dr. Charles A. Knight of the University of Washington.

\section{Bluish stratified ice}

This unit is composed predominently of bluish coarse-grained, equigranular, bubble-poor salty, stratified ice. Although cursory field inspection suggests that grain-size ranges from 2 to $8 \mathrm{~cm}$., Knight's laboratory study indicates that, because of the high degree of parallel crystallographic orientation over extensive areas, definition of what constitutes an individual crystal is highly arbitrary. As a result, apparent grain-size for this ice has little significance. Interlocking of crystals, such as reported from sea ice by Schwarzacher (1959, p. 2359) was not observed by Knight.

Study of stratified bluish ice exposures indicates that over wide areas the $c$-axis, as defined by the attitude of the basal platelets, was almost exclusively horizontal to sub-horizontal. Azimuthal orientation of the $c$-axis within the horizontal plane was generally random although preferential orientation of a very high degree was common locally. In such occurrences, areas as large as Io m. on a side exhibited almost perfect alignment. Knight reports personal communications from Stephen Nathanson and Harold Peyton that such alignment is commonly observed in sea ice (see also Schwarzacher (1959, p. 2359)).

\section{Table I. SAlinity Data}

Salinity values are in parts per thousand as determined by hydrometer corrected to $15^{\circ} \mathrm{C}$. Determinations made by William T. McComas and Thomas L. Garrett, U.S. Navy Hydrographic Office.

$\begin{array}{lccc}\text { Ice type } & \text { Number of samples } & \text { Range of values } & \text { Average salinity } \\ \text { Grey ice } & 18 & 0.6 \text { to } 0.9 & 0.8 \\ \text { Bluish ice } & 22 & 1.1 \text { to } 3.3 & 1.9 \\ \text { Banded ice } & 4 & 0.6 \text { to } 0.8 & 0.7 \\ \text { Septa ice } & 4 & 0.8 \text { to } 0.9 & \text { about } 0.9\end{array}$

Salinity data for the four major ice lithologies, based on hydrometric determinations, are summarized in Table I. Salinity of the bluish stratified ice varies with locality, ranging from $\mathrm{I} \cdot \mathrm{I}$ to $3 \cdot 3$ parts per thousand and averaging about I.9 parts per thousand. Samples collected to a depth of $2 \mathrm{~m}$. showed no significant variation in salinity with depth. 
Fish remains in varying degrees of preservation were common in and on the surface of the bluish ice. At least 30 individual articulated skeletons up to $60-75 \mathrm{~cm}$. long were found melting out at widely scattered localities. There can be no doubt that the source of these fish was the bluish ice; the mode of occurrence precluded their being transported by birds or animals. The fish, as yet unidentified, apparently were incorporated when the ice formed at the base of the section-surface melting has exposed them (Debenham, I920, p. 56-57, [r949], p. 205-o6; Crary, r96o, p. 44; Swithinbank and others, I96 I, p. 764).

The bluish ice unit is characterized by prominent stratification which, although best displayed in freshly exposed vertical faces such as illustrated in Figure 3, was also generally

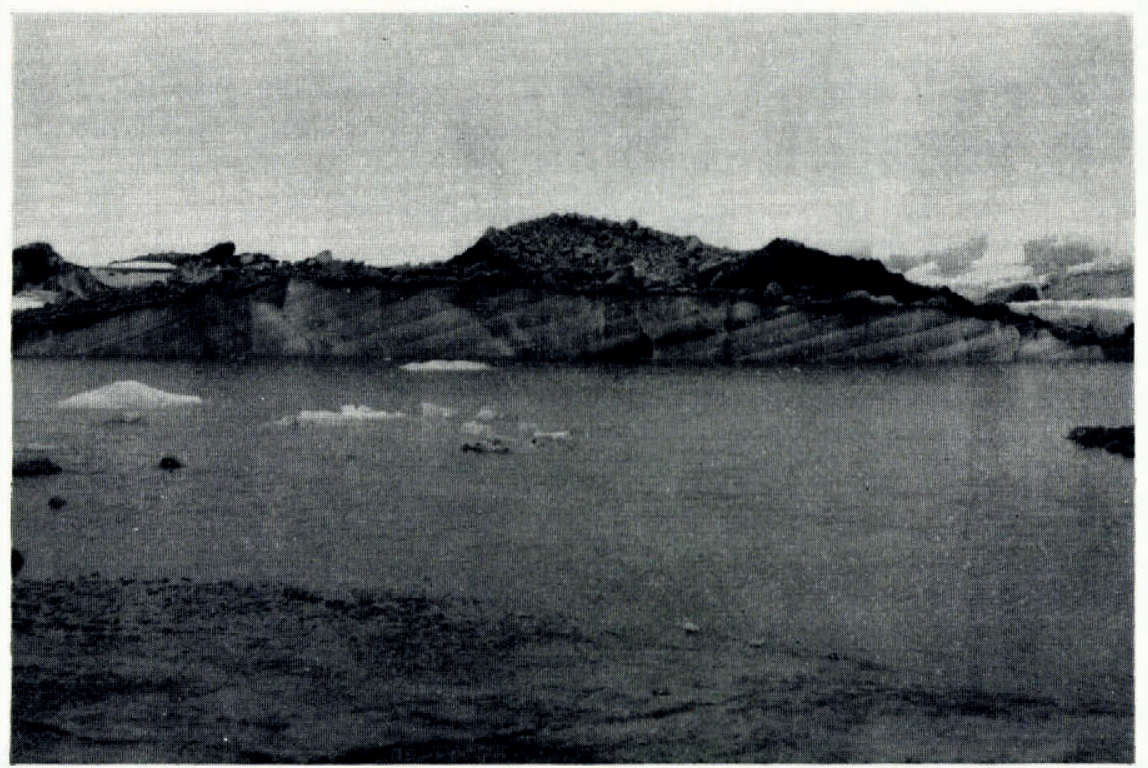

Fig. 3. Stratified sea ice exposed during fragmentation of "Halleluiah Hills" (Fig. 1o). Dip of stratification is structural in character and not the result of rotation of the block. Individual strata average 0.6 to $0.7 \mathrm{~m}$. thick

apparent on the weathered upper surface of the island. The stratification shown ranges in thickness from about 0.3 to $1.0 \mathrm{~m}$. and averages about 0.6 to $0.7 \mathrm{~m}$. On a fresh surface, individual strata generally show a marked color gradation from base to top; near the base they are bluish to dark blue grading upwards to a milky ice. This gradation may be the effect of variation in bubble and/or brine concentration in the ice. Such stratification may represent growth horizons but it is unlike the very thin layering seen in pack ice by Knight (personal communication in 1962) and the annual accretion layers in pack ice described by Schwarzacher (1959). No decision was reached as to whether or not this stratification is annual in character.

Along vertical contacts between the bluish and grey ice, the stratification is much more closely spaced and consistently dips at or near vertical. As shown in Figure $7 \mathrm{~A}$, stratification thickens and the dip flattens progressively away from the contact so that within 30 to $50 \mathrm{~m}$. the stratification approaches horizontal. This closely spaced, near-vertical stratification is characteristic of and limited to a relatively narrow zone adjacent to steep contacts. It is clearly a case of the stratification mimicing the shape of the glacial ice against which it was building up.

Locally, the bluish stratified ice sequence exhibits considerable lithologic variation. These atypical lithologies range from clearly defined horizons interbedded with the bluish ice to a 
gradual transition up-section through one or more units which are, in varying degrees, unlike the typical stratified ice. The most distinctive variant in the sequence is a prominent, ablationresistant horizon which crops out on the nose and limbs of the "Camp" and "August" anticlines (see Fig. Io). This unit varies in thickness from about $3 \mathrm{~m}$. in the "Camp" anticline to more than ro m. in the "August" anticline. Knight's examination of samples from this horizon indicated that (I) grain-size was very irregular, (2) neither crystal nor grain boundaries were orientated, and (3) the ice was definitely not sea or lake ice. Further consideration of the origin of this and other lithologic variants present within the sea-ice sequence is beyond the scope of the immediate problem.

Based on the petrographic characteristics and salt content of the stratified bluish ice, along with the presence of fish remains, the writer concludes that this unit formed by freezing of sea-water. Specifically, Knight's examination revealed that crystals of this ice show marked polygonization and sub-boundary development of the type that is a definitive characteristic of sea ice (Knight, I 962). Further, field study of this unit where the stratification was known to be horizontal, indicates that the $c$-axes of the crystals are almost exclusively horizontal and over extensive areas they show a high degree of azimuthal alignment. Both features are generally considered to be characteristic of sea ice.

The marked salinity of this ice supports a sea-water origin (see salinity data for old sea ice on $\mathrm{T}-3$ in Nakaya and Muguruma (1962, p. 5, figs. I6a, b) and Nakaya and others (1962, fig. 8o)). Although salt-water soaking of fresh-water ice is reported from T-3 (Crary, 1958, p. 35) and the ice shelf of Ellesmere Island (Marshall, I955, p. I Io), the fact that on ARLIS II the grey ice immediately adjacent to the blue ice, and at the same depth, has a very low salt content does not support a percolation origin for the salt in the blue ice. Furthermore, the petrographic relations do not indicate brine soaking.

\section{Grey foliated ice}

This lithology is composed of a grey, inequigranular, salt-poor, bubble-rich, foliated ice. Grain-size is rather irregular but typically it is $\mathrm{I}-2 \mathrm{~cm}$; smaller grains are not uncommon. Knight found that grain boundaries are irregular and had no orientation, and that there was also no evident crystallographic orientation. Sub-boundaries within the crystals are irregular "as results from deformation in glacial ice" (written communication from C. A. Knight in I96I). In addition, he observed microfaults across which crystal structures were discontinuous. The prominent foliation in the grey ice consists of alternating $2-5 \mathrm{~cm}$. wide bands of relatively bubble-free and bubble-rich ice. Knight stated that the air bubbles are generally less than I $\mathrm{mm}$. in diameter and are not elongated in a direction related to the folia. His work indicates there is no obvious relationship between the orientation of crystals and foliation in this ice.

The salt content of grey ice ranged from 0.6 to 0.9 parts per thousand (Table I). No significant variation in salinity with depth was observed. Rocky debris is abundant in zones within the grey ice. Although a careful search was made, no contained faunal material was found. Other than variation in foliation development in different areas of the island, the grey ice unit exhibited almost no lithologic variation.

On the basis of grain shape and size, the presence of irregular sub-boundaries and microfaults and the characteristic foliation, the writer concludes that the grey ice unit is glacial ice.

\section{Coarse banded ice}

This unit consists of coarse-grained, strikingly transparent, dark blue, salt-poor ice characterized by very prominent banding. Knight describes this ice as very heterogeneous in character. Grain-size ranges from a few centimeters to as much as 8 to $10 \mathrm{~cm}$. Porosity varies greatly and without evident pattern. In parts of a specimen, the layering is reflected by crystal texture-elsewhere, it is not. Knight observed no grain boundary or crystallographic orientation in the specimens studied. The prominent banding characteristic of this ice unit 
was best seen on weathered surfaces (Fig. 4). Bands averaged $25-30 \mathrm{~cm}$. apart and consisted of $\mathrm{I}-3 \mathrm{~cm}$. wide zones of much finer grained ice. As in the grey ice, crystal orientation and the banding were not related.

Banded ice has a low salt content, very close to that of the grey glacial ice; salinity values average 0.7 parts per thousand (Table I).

Although the clarity, low salinity and the lack of sub-boundary structures suggest a fresh-water origin, the lithologic evidence is not conclusive. Structural evidence bearing on its origin will be considered in a later section.

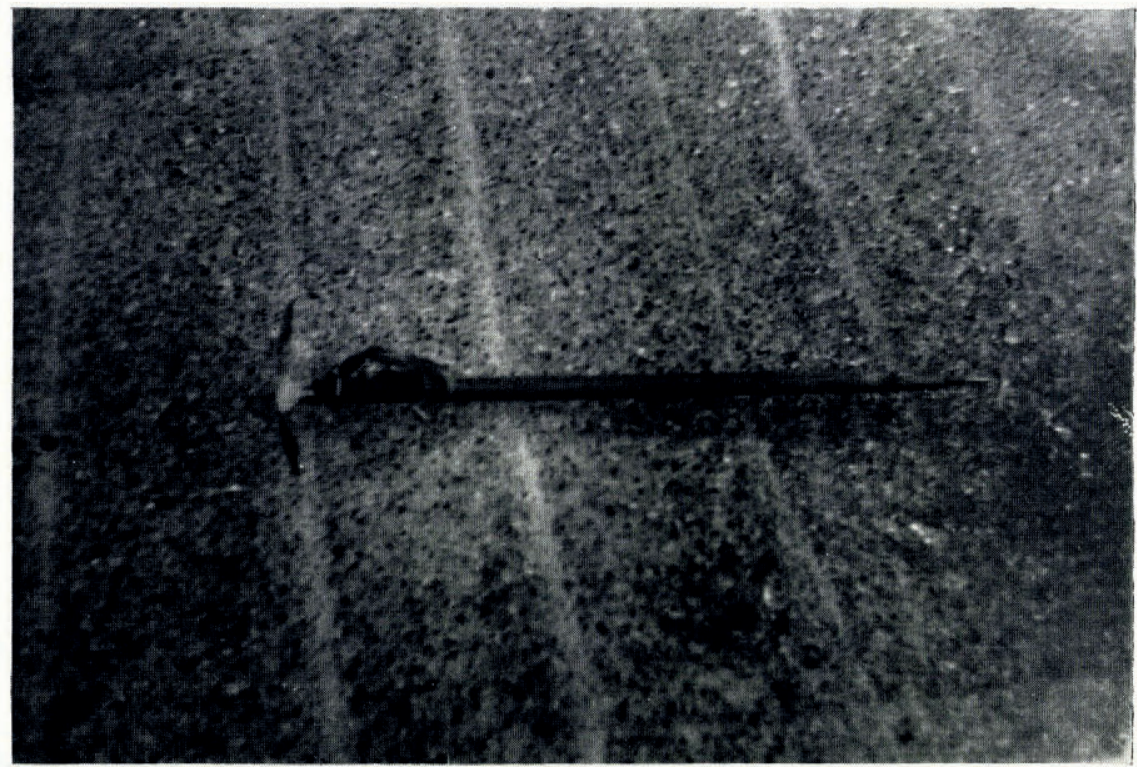

Fig. 4. Coarse-grained banded ice. Ice-axe about $0.9 \mathrm{~m}$. long. See Figure 10 for location

\section{Massive septa ice}

Massive ice occurs only in the steep to vertically dipping, elongate, tabular dike-like septa (described under "structures") within the grey ice. This ice unit consists of three distinct lithologies which intergrade laterally along the strike of the septa. The three, apparently interrelated facies of a single major ice type, are: (I) fine-grained, bubble-free bluish ice; (2) medium-grained bubble-rich ice; and (3) coarse-grained blue ice.

The fine-grained ice is most common, comprising $70-80$ per cent of the septa mapped. Crystals are very uniform and show no preferred orientation or substructures. The mediumgrained bubble-rich facies is noticeably equigranular and crystals average $\mathrm{I} \mathrm{cm}$.; a few have diameters of $2 \mathrm{~cm}$. No preferred orientation was observed. A rudimentary substructure was present in a few of the larger grains. The air bubbles show roughly vertical alignment. This lithology occurs as pronounced local bulges or enlargements on a given septum. The coarsegrained facies consists of interlocking grains averaging about $4^{-6} \mathrm{~cm}$. in diameter which commonly weathered out almost intact.

As shown in Table I, massive septa ice has a salt content of about 0.9 parts per thousand, almost identical to that of the enclosing glacial ice. Rocky debris is scattered through these septa but no faunal material was found. The petrographic characteristics of this ice and its low salt content indicate that it is of fresh-water origin. Further discussion is presented in the section on the origin of septa. 
Mud AND Debris Zones

The surface of ARLIS II is marked by a series of debris-covered hills and extensive mud flats. A few of the mud flats are the result of stream transport and subsequent depositional concentration. However, most of the mud sheets and virtually all of the masses of rocky debris are residual concentrations essentially in place with respect to their source horizons.

There are two principal types of source horizon on ARLIS II : (I) the debris zones paralleling the foliation within the grey ice and paralleling the banding in the banded ice, and (2) the mud and debris zones along the basal contact between the grey and blue ice. The first has no relation to the contact between the two ice types; the second has no relation to the foliation within the grey ice. Furthermore, the first is a structural feature; the second is stratigraphic in nature. This distinction is fundamental to an understanding of how the debris was incorporated in the ice of the island.

Four distinct petrologic assemblages are represented in the debris concentrations. These are: a granite suite, a mafic suite, a schist-gneiss suite and a sedimentary rock suite associated with pelecypod-rich muds. Except for one area where the suites are mixed, each assemblage is restricted to given parts of the island. Figure 5 summarizes their areal distribution. The granitic debris zone is restricted to the grey ice and parallels the foliation within it; the

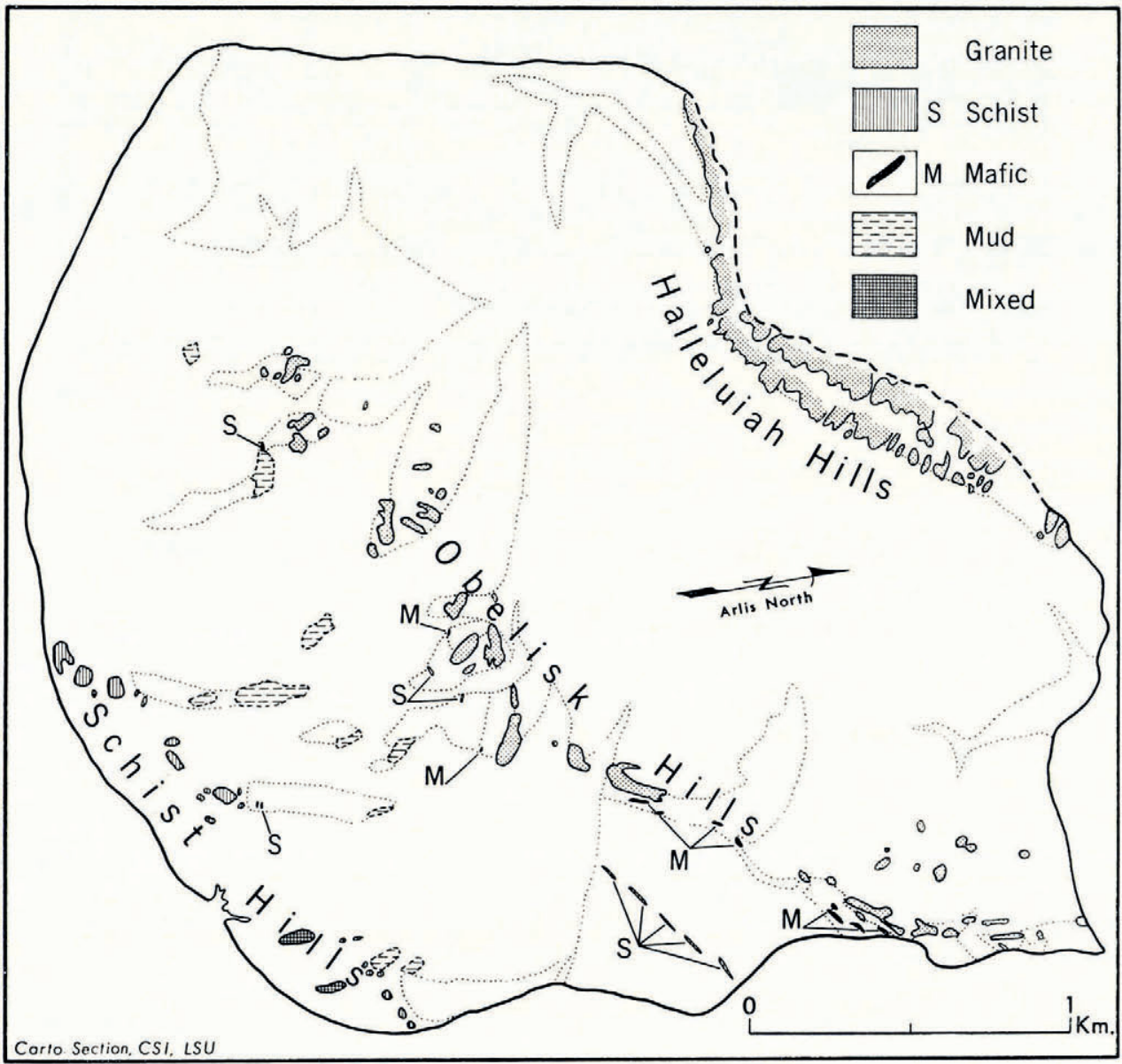

Fig. 5. Distribution of the five rock suites. Sedimentary rocks occur with the mud 
schist-gneiss zone has essentially similar relations. The mafic debris zone occurs only in the banded ice tongue and parallels the banding. Thus these three are structural in character; further consideration is deferred to the section on origin of structural features. Only the mud and associated sedinentary rock suite occur along the basal contact of the grey ice and are stratigraphic in character.

The muds in question occur primarily in an elongate discontinuous zone spaced roughly midway between the "Obelisk" and "Schist Hills" (Fig. 5). All occurrences are associated with isolated outlying blocks of grey ice rather than with the central mass proper. The outcrop of the mud horizon along the basal contact of the grey ice is shown in Figure 6. Several of these

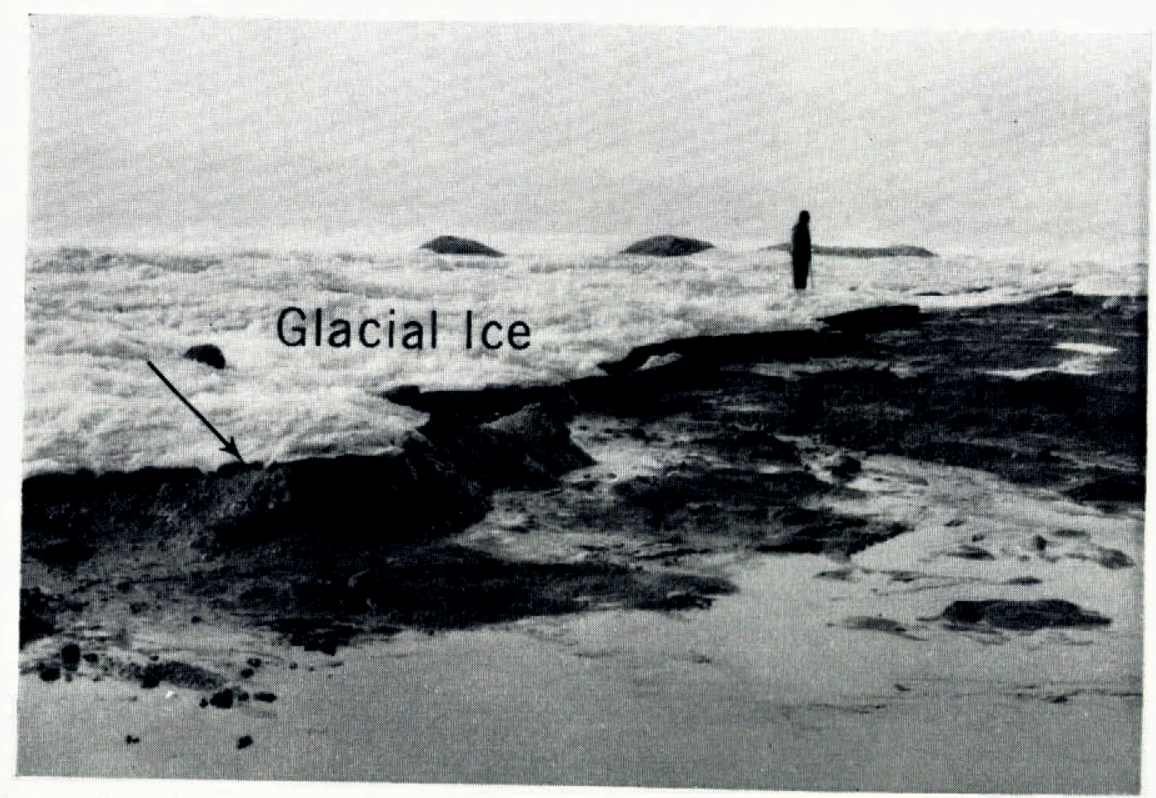
Fig. 6. Outcrop of mud horizon along contact (arrow) between grey glacial ice and underlying stratified sea ice. Note cobbles in
foreground. See Figure to

mud sheets contain abundant pelecypods and serpulid worm tubes, and a few small gastropods. Rocks in this association have attached worm tubes and occasional bryozoans. Clearly, these muds were originally marine bottom sediments. The logical conclusion is that the mud and associated sedimentary rocks were frozen to the base of the foliated grey glacial ice when that mass temporarily came in contact with the sea floor, probably in quite shallow water. Such adfreezing of mud and rocky debris must predate the addition of the stratified sea ice which underlies the mud horizon. Thus the mud constitutes a stratigraphic reference horizon of considerable significance in the developmental history of the island.

\section{Ice Structures}

Structurally, ARLIS II consists of a large, irregular central block of jointed, foliated grey glacial ice (Figs. 2 and ro). Along part of its periphery this block is bordered by extensive areas of stratified sea ice. A series of long, narrow, wedge-like sea-ice salients penetrate the margins of the central block, locally almost partitioning it. In the southern part of the island the sea-ice border has been deformed into two large plunging anticlinal folds. Scattered series of grey ice outliers separate the folds. Some of these structural features, particularly the 
preserved sea-ice salients and a series of folds in an ice tongue (described below) within the central block, apparently have not been treated previously in the literature. For convenience, the structures of the central block are considered first, and then the structures peripheral to it.

\section{Structures within the central block}

Foliation. The glacial ice of the central block is characterized by a prominent bubblesegregation foliation, the detailed small-scale characteristics of which have been described above. Although the strike of foliation varies considerably in different parts of the island, the overall pattern is crudely fan-shaped (Fig. Io). North of the "Obelisk Hills" the strike approximates north-south; near the "August" anticline the trend swings progressively north-west then west. Dip of the foliation is generally very steep, approaching vertical (Fig. Io). Locally, however, dips as low as $10-20^{\circ}$ were observed. The cliff face exposed when the north half of the island separated revealed small open folds in the foliation (Fig. 7) as well as local, tight crenulations. Dip of the foliation in the limbs of the folds varied from Io to $35^{\circ}$.

Debris zones. The mafic, schist-gneiss and granitic debris zones are important structural features within the central block (Fig. 5). Their structural relations are described on p. 24 . The schists occur as a narrow discontinuous stringer about $300 \mathrm{~m}$. south-east of the "Obelisk Hills". The stringer is restricted to the grey ice and parallels its foliation. An identical schistgneiss assemblage comprises the extensive debris cover in the "Schist Hills" some I, oooI,200 m. farther south. Most of these hills are adjacent to the southern end of the grey ice outliers and the trend of the hills parallels the trend of the foliation within the outliers. In the writer's opinion, the source of this material is one or more debris zones within the grey ice.

Granitic debris comprising the "Obelisk" and "Halleluiah Hills" covers extensive areas (Figs. 5 and 10). Where actually observed melting out of the ice, the debris was orientated parallel to the foliation and occurred as pod-like or lensoid bodies of limited lateral extent. Thus a given debris zone is quite discontinuous. In addition, at about half of the in-place localities, the strike of the foliation and the debris zone diverged as much as 30 to $50^{\circ}$ from the general trend of the chain of hills. This suggests that an en échelon orientation of the debris concentration results in the linear pattern of the hills.

The granitic debris zones are involved in some of the small, gentle fold structures in the north-east quadrant of the island (Fig. ro, section $\mathrm{c}-\mathrm{c}^{\prime}$ ). In addition, the sections exposed during fragmentation of the "Halleluiah Hills" showed tight folding and crenulation in the debris zones. Bedded silts and sands occur locally with the granitic debris; bedding is orientated vertically and its strike parallels the trend of the debris zone. These beds are in place and, at a depth of 0.5 to $\mathrm{I} \cdot \mathrm{O} \mathrm{m}$., are continuous with the source debris zone in the underlying ice. Interbedded moss-like plant material indicates the beds were deposited horizontally under subaerial conditions and were subsequently incorporated in the ice and deformed to the present vertical orientation.

Septa. A series of conspicuous sub-parallel, locally interconnected dike-like septa, composed primarily of massive fresh-water ice, are characteristic features of the south-east margin of the central block and of many of its outliers (Fig. 10). These bodies are tabular in form, and are generally orientated vertically or nearly so. Some narrow septa, observed in section, pinched out before reaching the present surface of the island.

Throughout extensive areas septa are predominantly parallel to the strike of the foliation in the enclosing grey ice; elsewhere they range from parallel to sharply crosscutting. Typically they occur as a series of sub-parallel longitudinal members connected locally by crossbars. At many localities they branch and interconnect irregularly. Individual septa range in width from I $\mathrm{m}$. or less to as much as $50 \mathrm{~m}$. locally, and average about $3-4 \mathrm{~m}$. wide. Unusually wide septa appear to be the result of juncture or merging of several bodies. Distances between longitudinal septa vary from area to area but average about $30^{0-50} \mathrm{~m}$. 


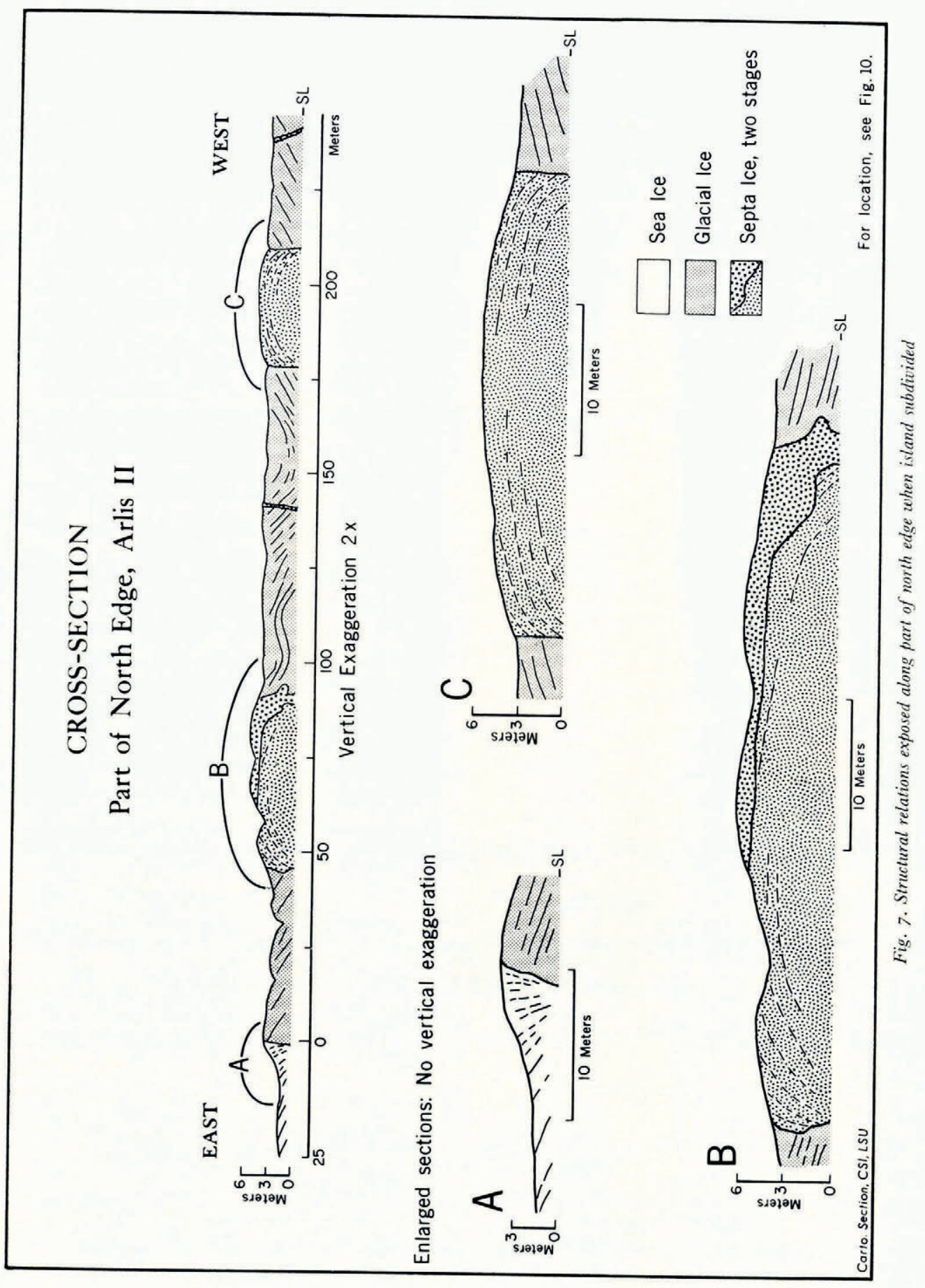


Although quite evident on the map (Fig. IO), crosscutting of foliation by septa was best seen in the fracture-produced exposures along the north edge of the island (Fig. 7). One of the septa illustrated consists of two units: a large lower body characterized by prominent arch-like bands, and a thinner upper body, locally almost flat-lying, apparently cutting both the enclosing grey ice and the other septum. Elsewhere, on a near-vertical face of an underwater projection clearly visible to depths of Io or $12 \mathrm{~m}$., two steeply dipping septa were observed to intersect about $8 \mathrm{~m}$. below water level. These relations argue strongly for at least two stages of septa development.

The arcuate banding shown in Figures $7 \mathrm{~B}$ and ${ }_{7} \mathrm{C}$ is characteristic of almost all septa more than 2 to $3 \mathrm{~m}$. wide, observed in section. This banding is the trace of a series of nested, arched planar surfaces present within the septa. Locally, the trace of these features was visible on the upper surface. These arched surfaces are strikingly similar to the arch-like form of the stratification characteristic of the bluish sea ice adjacent to near-vertical contacts with grey ice bodies (Fig. 7A). As described earlier, the stratification is thought to represent growth horizons. The arched, planar surfaces in the septa appear to be of the same origin.

Scattered patches of granitic debris were present in several of the smaller septa observed in cross-section along the north edge of the island. In addition, although debris was not observed melting out of the septa on the surface, a striking correlation exists between their position and the location of hundreds of small debris piles which dot the ice surface throughout the area. These small debris piles are clearly lag concentrates resulting from debris melting out of the septa.

Banded-ice tongue. A large, elongate, north-west trending tongue-like bcdy of tightly folded, coarse, banded ice is present near the south-east margin of the central block (Fig. Io). Although contained wholly within the central block, the tongue crosscuts the foliation, the granitic debris zones, and the septa in the grey ice. At the base of the tongue, a relatively narrow mass of banded ice extends out from the tongue several hundred meters to the northeast and south-west, roughly parallel to the foliation within the grey ice. Together, the two

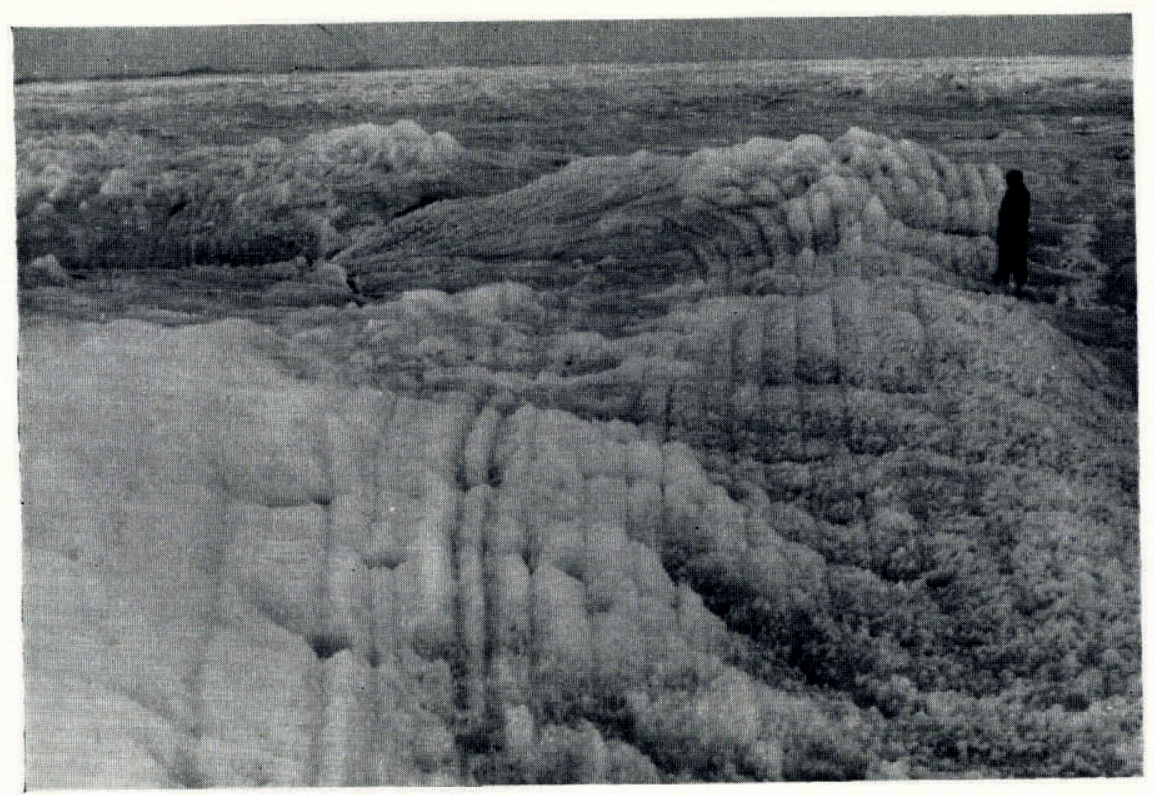

Fig. 8. Tight, steeply plunging folds in tongue of coarse, banded ice. See Figure ro 
elements form a crude T-shaped body. Smaller, discontinuous bodies of banded ice are also present at scattered localities to the south-west along the strike of the "Obelisk Hills" (Fig. Io). The tongue is about $600 \mathrm{~m}$. long and $\mathrm{I} 75 \mathrm{~m}$. wide near its base. The crossbar of the "T" is typically $75 \mathrm{~m}$. wide and, ignoring one minor break, about $\mathrm{I}, 000 \mathrm{~m}$. long.

In the crossbar of the " $T$ " the strike of the banding parallels the trend of the body, and the dip is very stecp to vertical. In the tongue proper, however, a series of very tight, steeply northward plunging folds are present (Figs. 8 and Io). These folds are particularly clear in the more resistant ice horizons which form a band trending diagonally across the tongue. In spite of this intense folding, the contact between the south-west edge of the tongue and the enclosing grey ice, although somewhat irregular, is not involved in the deformation. In addition,

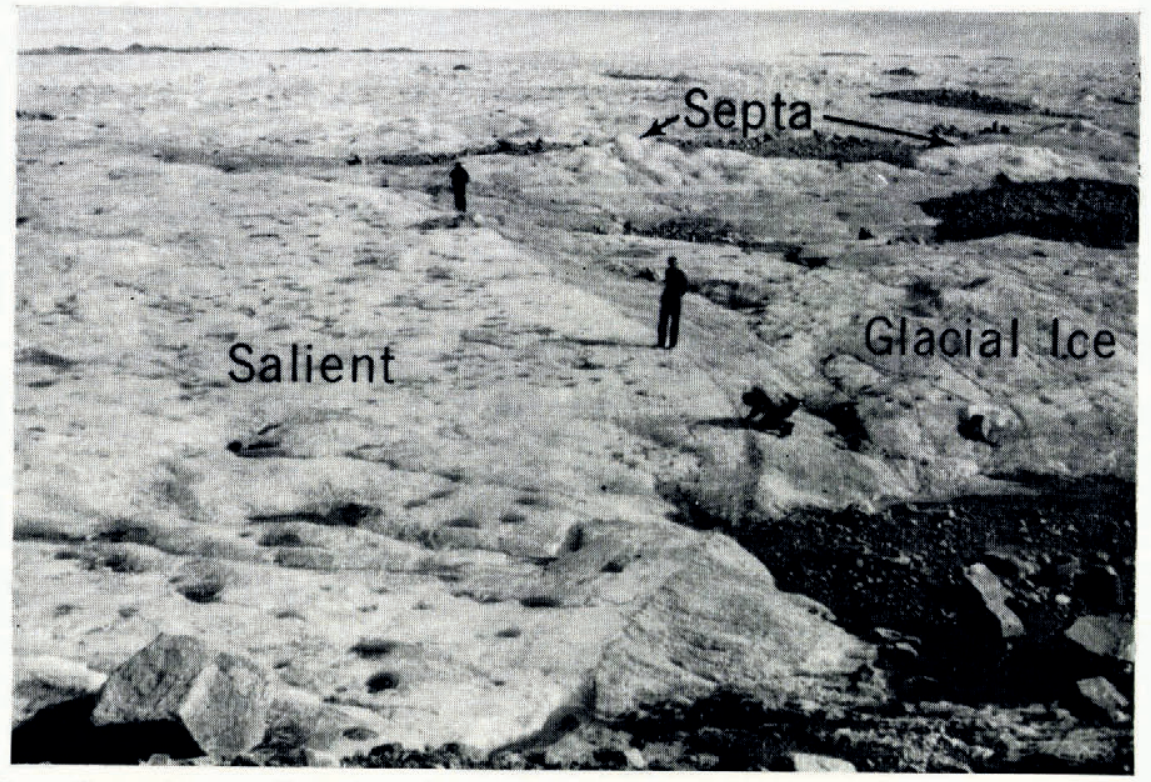

Fig. 9. Contact between salient of stratified sea ice and glacial ice along edge of "Obelisk Hills" (Fig. Io)

the contact along the north-east edge is, except for three small finger-like extensions, even more regular. Further, the foliation and the septa in the grey ice adjacent to the contacts are not disturbed. Although the crossbar of the "T" approximately parallels the trend of the foliation and septa within the grey ice, very detailed mapping of the contacts shows that it, too, crosscuts these structures.

Paralleling the banding within the crossbar of the major banded ice body are several narrow stringers of distinctive mafic igneous rocks. Smaller accumulations of mafic rocks are also present at two localities in the bodies to the south-west. By contrast it should be noted that the tightly folded ice in the tongue proper has no rock material present. At several localities large mounds of granitic debris overlie banded ice; such occurrences are limited to a zone along the contact between the banded ice and the foliated grey ice. The grey ice is almost certainly the direct or indirect source of this debris.

\section{Structures peripheral to the central block}

Salients. The margins of the central block (Fig. Io) are noticeably irregular, penetrated by a series of crudely wedge-shaped indentations which vary greatly in size. These indentations are occupied by sea ice on the order of $20 \mathrm{~m}$. thick. Such bodies of sea ice are important 
structural features on ARLIS II and are worthy of consideration in some detail. They are here referred to as sea-ice salients or, simply, salients. They range in length from $100 \mathrm{~m}$. to as much as $900 \mathrm{~m}$., and in width from a few meters near their apices to an average of about $100-200 \mathrm{~m}$. near their bases. The largest salient on ARLIS II, however, is about $45^{\circ} \mathrm{m}$. across at the base. Many salients change trend noticeably; several branch or subdivide at various angles; others are barbed or hooked. Some distal extensions of the smaller salients interconnect.

Salients crosscut the various structures and debris zones within the grey ice, and the boundary (Fig. 9) between the salient and the adjacent host ice is essentially vertical whereever it was observed, except in some of the grey glacial-ice outliers described below and along the inner margin of the "Halleluiah Hills". In the latter area the contact between the sea ice and the central block is extremely irregular (Fig. Io, section $\mathrm{E}-\mathrm{E}^{\prime}$ ), and dips range from nearly vertical to less than $25^{\circ}$. Contact relations in this area are, nevertheless, clearly crosscutting.

Although the salients consist primarily of stratified sea ice, many contain one or more moderately extensive but irregular zones unlike the typical stratified ice in texture, color and weathering product. Unfortunately time did not permit study of these lithologic variants. Based on the limited evidence available, it seems probable that some are fresh-water ice and others are the result of admixture of other types of ice with sea-water at the time it was freezing.

Some of the salients (Fig. Io) also contain small poorly preserved plunging folds at scattered localities. The mode of preservation of these structures, particularly the way in which they fade laterally, suggests partial digestion similar to that observed in some igneous and metamorphic rocks. These relations indicate that at least some of the ice within the salients has experienced a moderately involved developmental history.

Near the south-west corner of the island, two narrow elongate bodies of ice penetrate the central block (Fig. Io) and are in turn cut off by sea-ice salients. The two bodies are virtually identical to the narrow distal extensions of salients present elsewhere on the island and thus are so interpreted. Because the bodies are crosscut by the salients, however, they apparently represent an earlier generation of salient development.

Grey glacial-ice outliers. Although the southern third of ARLIS II consists primarily of stratified sea ice, five elongate north-south trending groups of foliated, glacial-ice outliers are scattered across this area. The shape, size, continuity and spacing of outliers within a given group varies. Typically, however, the larger outliers are about $100 \mathrm{~m}$. wide and $300-500 \mathrm{~m}$. long. Dip of the contact between a given body and the adjacent stratified sea ice is generally near vertical, except at the north end of several of the bodies where the mud horizon along the basal contact crops out (Fig. 6). In these areas dips as low as $10-30^{\circ}$ are common (Fig. I0).

These grey-ice bodies are almost certainly the remnants of long, narrow, formerly continuous finger-like projections extending to the south and south-east from the central block of glacial ice. The base of these projections is apparently quite irregular; $2-3 \mathrm{~m}$. of relief was observed at several localities. The existing remnants must represent deeper root-like parts of the original projections. Because of greater initial thickness, these areas remain - the thinner segments having since been lost to ablation.

Fold structures. Interspersed with the grey-ice outliers are several broad areas of stratified sea ice, 300 to $600 \mathrm{~m}$. wide and as much as $1,000 \mathrm{~m}$. long. Within these areas of sea ice are developed a series of irregular, poorly defined, gentle, warped structures and two prominent plunging anticlinal noses. Only the anticlines are considered here.

The "Camp" anticline consists of a large north-north-west trending, symmetric anticlinal nose and a smaller westward trending nose along the west limb of the major structure (Fig. 10). The main nose plunges to the north at about $25-30^{\circ}$; the minor one to the west at about the same angle. The structure, which dies out to the south, has a mappable length of about $600 \mathrm{~m}$. and, disregarding the minor nose, a width of about $300 \mathrm{~m}$. 


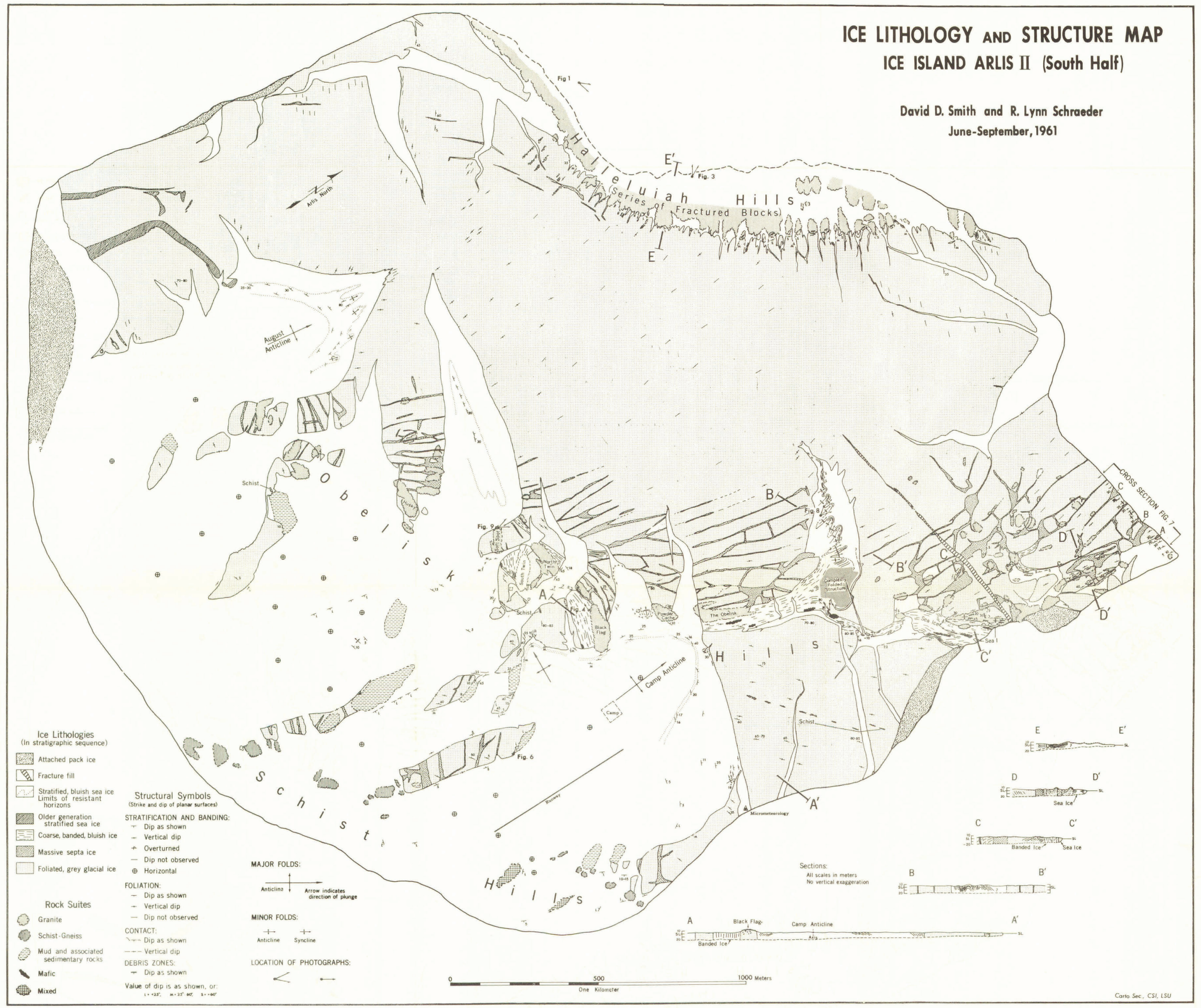


Both noses are marked by a distinctive horizon of resistant fresh-water ice several meters thick which locally forms a ridge $\mathrm{I}-2 \mathrm{~m}$. high. For the main structure, values of dip measured on this horizon range from $10-20^{\circ}$ on the east limb to $25^{-} 40^{\circ}$ on the nose; the limbs of the minor fold have somewhat steeper dips. Locally, on the nose of the main structure, small isolated relatively tight plunging folds are present (Fig. Io).

The "August" anticline, near the south-west corner of the island, is a broad slightly asymmetric north-south trending anticlinal nose which occupies the greater part of one of the largest salients on the island. The fold dies out to the south; its mappable length of $300 \mathrm{~m}$. is only slightly greater than its width. This anticline is also marked by a prominent ridgeforming horizon which sweeps around the nose in an arc. Although dips on this horizon along the west limb are as steep as $25-30^{\circ}$, the ridge averages about $50-60 \mathrm{~m}$. wide, indicating that the horizon is much thicker here than the equivalent (but not necessarily correlative) horizon in the "Camp" anticline. A complicated series of very tight steeply plunging minor folds (Fig. Io) is present on the extreme nose of the fold, and at scattered localities along the east limb.

Reconnaissance work in the "Halleluiah Hills" area prior to their fragmentation indicated the presence of several somewhat smaller anticlinal and domal structures in the stratified sea ice of that area. Insufficient data, however, prevent adequate description here.

In addition to the "Camp" and "August" anticlines, several other salients have central core-like masses of ablation-resistant ridge-forming ice. Except in the "Soft Spot" salient, this ice was not involved in any recognizable structures. In the "Soft Spot" salient (Fig. Io) the resistant unit formed an east-west trending homoclinal mass dipping uniformly to the north at $20^{\circ}$. The mass appears to be an isolated block surrounded by finer-grained less resistant ice in which no structural relations could be established.

\section{Origin of Structural Features}

\section{Foliation}

The bubble-segregation foliation characteristic of the grey ice is apparently relict to the former stress field related to flow of the glacier of which this ice was once a part. (For detailed discussions of foliation, see Untersteiner (1954, p. 240, 1955, p. 504), Allen and others (196o, p. 6o6-07, 6r 7-20) and Meier (196o, p. 52-54, 59-6o)). The structures defined by the foliation on ARLIS II are thus the remnants of larger structural patterns present in the source glacier.

The crude fan-like map pattern defined by the ARLIS II foliation does not correspond closely to foliation patterns typical of most valley glaciers. However, on the premise that the elongate debris zones represent medial moraines (see below), the foliation in the vicinity of the "Schist" and "Obelisk Hills" would be longitudinal in character because it parallels the trend of the hills. Longitudinal foliation is characteristic of the marginal areas of many valley glaciers and occurs throughout almost the entire extent of some valley glaciers (Untersteiner, I955, fig. I; Meier, I96o, p. 54, plate 2). On the other hand, the foliation in the "Halleluiah Hills" area strikes at right angles or obliquely to the trend of the hills. Although transverse or oblique foliation is characteristic of the medial area of some ice streams (Allen and others, I96o, fig. 3) and the terminus area of most valley glaciers (Sharp, i96o, p. 57), the transverse foliation on ARLIS II does not lend itself to this interpretation because of its relation to the overall fan-like pattern. In short, with the limited evidence available, the full significance of the foliation pattern in the grey ice is not clear.

\section{Debris zones}

The parallelism of the debris concentrations with the foliation in the grey ice, along with other evidence, indicates that the debris zones are relict features inherited from the original source glacier. Thus the elongate belts of debris (Fig. 5) were morainal zones within the parent 
glacier. The relationship of the debris to the present configuration of the grey-ice mass suggests that these moraines were probably medial.

\section{Septa}

Because these dike-like bodies crosscut the foliation and debris zones, it seems likely that they are filled fractures. Further, the absence of foliation within the septa indicates that these fracture fillings apparently formed after glacial flow had ceased. Thus, at the time of fracture filling, the host ice was apparently somewhere near the terminus of the parent glacier.

The following lines of evidence support a crevasse-fill origin for most of the septa: (I) based on petrographic characteristics and salinity data the ice of the septa is of fresh-water origin; (2) the three distinct ice lithologies within the septa suggest variation in conditions at the time of formation such as might be expected in a crevasse fill; (3) the presence of scattered rocky debris in the septa suggests a crevasse origin.

Some septa, however, apparently formed as fillings of fractures in the base of the ice mass. It seems probable that a glacier tongue afloat could develop tensional crevasse-like fractures at its base. The evidence supporting such an origin includes: (I) some septa pinch out as they approach the present surface of the island; (2) in Figure $7 \mathrm{~B}$, the younger septum narrows and flattens to almost horizontal - such flattening is not characteristic of a typical crevasse; (3) the arched planar banding within some of the septa (Figs. $7 \mathrm{~B}$ and ${ }_{7} \mathrm{C}$ ) suggests freezing from the top down in a body of standing water; and (4) the fresh-water character of the ice of the septa does not preclude development as basal fracture fills inasmuch as a fresh-water layer about $6 \cdot 5 \mathrm{~m}$. thick has been reported (Lyons and Leavitt, I96r, p. 8) as being present beneath the base of the ice shelf of Ellesmere Island along its inner edge near the end of the melt season (see also Marshall (I955, p. I12) and Crary (I956, p. I6 I)).

Filled crevasses are reported from Antarctic ice by Wright and Priestley (1922, p. 239-40, figs. 89, I 73, plates 95, I 57, I 58), Gould (1935, p. I382), Nichols ([1953], p. I 20-22, fig. 91), and from North American glaciers by Sharp (1947, p. 32 ; 1960, p. 49) and Kamb (1959, p. I899). Marshall (1960, p. 47) mentions rehealed crevasses in ice shelf basement but does not describe them. Except for the features mentioned by Marshall (1960), the crevasse fills cited were either in the process of formation or had formed relatively recently (Nichols, [1953], p. 122). To the writer's knowledge, extensive systems of preserved crevasse fills, possibly several thousand years old (Crary, i96o, p. 46; Lyons and Leavitt, i 96r, p. 34-35), such as the septa on ARLIS II, have not been previously described. Insofar as is known to the writer, there are no features described in the literature which may represent basal fracture fills. The rather unusual circumstances required to observe such features may in part explain this absence.

Based on the descriptions of healed fractures on the Ward Hunt Ice Shelf (Crary, I958, p. I8-24; Lyons and Leavitt, I96I, p. I9, fig. 7) and on T-3 (Cabaniss, I96I, p. 39, fig. 5), and on field evidence seen by the writer on $\mathrm{T}-3$ in 1958 , the ARLIS II septa are distinctly different features. Only one large healed fracture was found on ARLIS II (Fig. IO).

\section{Salients}

The sea-ice salients apparently formed in wedge-shaped re-entrants developed in the central block by fracturing. Strikingly similar indentate fractures along the margins of shelf ice and floating glacier tongues in the Antarctic are figured by Siple (1945, fig. 3 I) who calls them "tension bays" and by Poulter ([1950], fig. 34) and [Roscoe] (r953, p. 43-46), and in northern Greenland by Helk and Dunbar* (1953, figs. 6, 7) and Ahnert (1963, figs. 3 and 4). In addition, a series of quite similar re-entrants are present in a glacier tongue merging with shelf ice in Ayles Bay, along the north coast of Ellesmere Island (Marshall, 1960, fig. 12). See also Taylor and Lyons (1959, plate I) and Barnes (1960, fig. 26). Thus, at least one

\footnotetext{
* Miss M. Dunbar kindly loaned additional unpublished photographs of these features for study by the writer.
} 
glacier in the vicinity of the ice shelf of Ellesmere Island presently has a series of re-entrants of roughly the same form as those along the margins of the central block of foliated glacial ice on ARLIS II. It seems reasonable to assume that other glaciers along the Ellesmere Island coast had similar indentate features sometime in the past when the ice which makes up ARLIS II was forming. Of the papers cited, Helk and Dunbar were first to point out the rather unusual character of these indentate forms; they refer to the finger-like projections between the reentrants as having the shape of a bird's wing. Only Ahnert considers the problem of the development of these features.

Most of the salients on ARLIS II occupy indentations which apparently formed as simple fractures resulting from splitting of the glacier terminus with attendant opening out along the fractures. This conclusion agrees with that of Ahnert (I 963 , p. 544). By contrast, however, a few of the indentations, even though highly irregular in plan and locally recurved, apparently have not formed by any appreciable rotational separation or opening out of the walls, as shown by the parallelism of septa and foliation in the host ice on opposite sides of the reentrant (cf. Fig. Io, the salient between "Soft Spot" and "Husky", and between "Powder Cache" and "The Obelisk"). These irregular or recurved re-entrants probably developed by progressive fragmentation.

\section{Banded-ice tongue}

Although the intensely folded character of the banded-ice tongue superficially suggests a glacial stress origin, considerable evidence indicates that the tongue postdates the flow of the parent glacier and is definitely non-glacial in origin. The map pattern of the banded-ice tongue is noticeably similar in form and size to the sea-ice salients on ARLIS II. The crosscutting character of the tongue and the vertical nature of its contact with the enclosing glacial ice is also characteristic of these salients. These obvious similarities argue strongly that the banded-ice tongue formed initially as a salient which subsequently has been deformed to its present tightly folded character.

Although the bulk of this banded ice formed from fresh water, the following lines of evidence indicate that this composition does not rule out the proposed salient origin. As described above (p. 32), fresh water is present locally at the base of the ice shelf of Ellesmere Island. In addition, run-off from melting glaciers at the inner ends of the long fiords along the Ellesmere Island coast probably develops a similar or possibly thicker layer of fresh water under the ice in these fiords (Marshall, I955, p. I 12; Crary, I956, p. I6I). It thus seems quite possible that re-entrants formed in a glacier tongue located in the inner part of one of these fiords would be filled with fresh-water ice.

Furthermore, the earlier generation of sea-ice salients cutting the grey ice near the southwest corner of the island locally displays a banding similar to that of the banded ice. These features perhaps represent a stage of development intermediate to the sea-ice salients and the banded-ice body in question.

As described earlier, the tight folds within the banded-ice tongue have not disturbed the structures in the enclosing grey ice. Consideration of the available evidence suggests that the folds in the tongue are actually the result of compressional stresses directed against the salient by the crowding of the large grey-ice block immediately to the south. From the structural viewpoint, tight folding might be expected to develop in a wedge-shaped re-entrant as a result of such compression. Further, if the ice in the re-entrant was relatively thin with respect to the adjacent grey ice, the folding might very well have little or no effect on the contact proper, let alone the internal structures within the grey ice across the contact. These are precisely the relations, seemingly anomalous, which are observed in and adjacent to the banded-ice tongue.

The steep plunge of the folds in the tongue may well be the result of the initial configuration of the re-entrant. There is, it would seem, a situation crudely analogous to the deform- 
ation and molding of a softer material under compression to fit the walls of its more competent container.

The strike of the foliation in the block of grey ice to the south of the tongue differs by 30 to $40^{\circ}$ from the strike of the foliation in the grey ice on the north and north-west side of the banded tongue, suggesting that a change in orientation and thus movement of the southern block may have occurred. In addition, the banding in the crossbar of the T-shaped body curves around into the tongue (Fig. Io) suggesting flowage of the ice into the re-entrant. Although not conclusive, the evidence favors slight movement of the adjacent southern greyice block as the probable source for the compressional forces which folded the banded ice in the tongue.

The source of the mafic igneous debris stringers present in the banded ice is difficult to explain. The presence of scattered serpulid worm tubes in this debris at one locality suggests that it was picked up off the bottom. When the ice unit was folded this debris may have been incorporated by shearing or infolding.

\section{Fold structures}

The tight, plunging character of the minor folds around the nose of the "August" anticline favors a compressional origin. Similar but generally less tight and less extensive minor folds are also present at scattered localities on the nose of the "Camp" anticline.

As apparent in Figure Io, the "August" anticline is virtually co-extensive with the inner part of one of the largest salients on the island. This salient is constricted noticeably to the south of the anticline. To a lesser degree the "Camp" anticline is also flanked by projections of the central block and by grey-ice outliers. The position of the two anticlinal noses near the apices of major re-entrants walled by masses of grey ice, together with the fact that both structures die out toward the mouths of these re-entrants, suggests pinching of the apical areas as the cause of the two anticlines. Such pinching might be the result of slight compressional movement of the re-entrant walls in a manner somewhat similar to a nutcracker.

On the other hand, the broad, relatively gentle, arch-like character of the two structures is atypical with respect to most fold structures developed in relatively thin ice and thought to be of compressional origin. In the examples of folds reported for ice on the order of $3 \mathrm{O}^{-} 35 \mathrm{~m}$. thick or less, and where a compressional origin has been moderately well demonstrated, the folds typically have a smaller wavelength and amplitude.

The relatively gentle folds along the inner margin of the Ward Hunt Ice Shelf (Lyons and Leavitt, I96I, figs. 6 and 7) have crest to trough dimensions of about $200 \mathrm{~m}$., which is about one-half to two-thirds the size of the major ARLIS II structures. Lyons and Leavitt conclude that these folds are the result of compression by an advancing glacier.

Folds in a stratified ice unit in the basement ice near Colby Bay on T-3 (Cabaniss, I96I, p. 37, fig. I ; Nakaya and others, I962, fig. 81) may also be the result of glacial compression. Where examined by the writer in $195^{8}$ and $196 \mathrm{I}$, they range from gentle open to tight isoclinal folds, the axes of which are typically horizontal and 15 to $30 \mathrm{~m}$. apart. Locally, some of the basement ice is highly contorted (Smith, r960, p. 36 , plate $9^{B}$ ) and the still smaller-scale folds present have a steep plunge. The majority of the folds seen on $\mathrm{T}-3$ are of the same order of magnitude as the small folds on the noses of the ARLIS II anticlines.

Siple (1945, fig. 39), Poulter (1947, figs. 3, 4; [1950], fig. 32), Nichols ([1953], p. I30--31), and Macdonald and Hatherton (1961, p. 863) report or figure a series of anticlinal and synclinal folds in Antarctic bay ice. Macdonald and Hatherton's folds have a $25 \mathrm{~m}$. wavelength. Although dimensions are not given in the other papers, the folds shown appear to have wavelengths on the order of 60 to $90 \mathrm{~m}$.

Thus the dimensions of the two ARLIS II structures (Fig. I0) are half again to twice as large as the folds reported in the ice shelf of Ellesmere Island, and more than 5 to ro times larger than the folds on $\mathrm{T}-3$ and in the Antarctic bay ice. Siple (1945, fig. 40), Zumberge 
(1958, p. 795; 1960, p. 62) and others report folds with greater amplitudes and/or wavelengths in the Antarctic shelf ice, but the magnitude of thickness involved is much greater than in the ice shelf of Ellesmere Island or the ice islands. Thus, it appears that the broad arch-like character of these two anticlinal structures in a plate of ice about $20-25 \mathrm{~m}$. thick does not support a compressional origin.

On the other hand, there is some evidence for differential ablation on ARLIS II which might result in warping. Detailed ablation data collected during the $196 \mathrm{I}$ melt season by R. Lynn Schraeder indicate that the stratified sea ice ablates about 12 per cent faster than the foliated glacial ice. This difference in ablation rate resulted in a $20 \mathrm{~cm}$. difference in ice loss for the two types that season. If maintained over a period of years, this might well result in upwarping of the differentially thinned sea-ice areas. Although Lyons and Leavitt (I96I, p. I8) conclude that along the inner margin of the Ward Hunt Ice Shelf, warping caused by differential ablation amounts to only $\mathrm{I} \cdot 5^{\circ}$, the contrast in ablation rates for sea ice and glacial ice on ARLIS II may be greater than the contrast between the upper and lower units of the ice shelf. Such a relationship is suggested by Hanson's (196r, p. 195-96) data on the contrast in albedo values for shelf ice and sea ice.

Because the smaller-scale tight folds on the nose and limbs of the two anticlines and the asymmetry of the "August" anticline suggest compressional forces, and the broad arch-like character of the large structures suggests warping, a combination of compressional forces and warping seems to best explain the structural relations observed.

\section{Probable Sequence of Development of ARlis II Structures}

(I) A large valley glacier containing several debris zones was afloat in a fiord along the north-west coast of Ellesmere Island. The foliation pattern in the ARLIS II ice is relict to the flow of this glacier. (2) A series of long narrow sub-parallel crevasses and basal fractures developed in the glacier. These subsequently filled with fresh-water ice in two or more stages to form septa. (3) The mass of glacial ice grounded locally and picked up a thin basal layer of pelecypod-rich mud and associated sedimentary rocks. (4) Fracturing in the glacial ice opened a large irregular re-entrant, one tongue-like bay of which cut across a debris zone (now the "Obelisk Hills") and the adjacent septa. The re-entrant developed a fill of freshwater ice which gradually increased in thickness. (5) As this re-entrant fill thickened, it was subjected to compression by a flanking mass of glacial ice and developed a series of tight, steeply plunging folds. (6) Another stage of fracturing and re-entrant development occurred during which the older-generation salients preserved near the south-west corner of ARLIS II were formed. (7) A series of close-spaced, sub-parallel re-entrants opened along both margins of the glacial mass and a thick fill developed to form the youngest salients. (8) Compressive forces produced the relatively small-scale tight folds near the apices of some of these salients. (9) Warping, probably caused by differential ablation during a period of downmelting of the ice shelf surface, produced the broad arch-like anticlinal structures. (Io) Build-up of the iced firn and lake ice cover (described in next section) over the basement ice then occurred. (I I) Partial fragmentation of the ice shelf along the Ellesmere Island coast released the mass which, with further reduction by fragmentation and thinning, we now know as ARLIS II. (12) Continued ablation during the drifting phase removed the iced firn and lake ice cover exposing the basement ice, and may have renewed warping of the anticlinal structures.

It seems likely that the period of ablation related to development of the broad anticlinal structures ((9) above) was the same as that which produced the unconformity between the basement and upper units of the ice shelf of Ellesmere Island (Crary and others, I955, p. I I 72; Lyons and Leavitt, I96I, p. 32, 34). Thus (I) through (8) above presumably are equivalent to the sequence of events which mark the development of the ice shelf basement in the Ward Hunt Island area (and probably elsewhere). Included in the Ward Hunt Island sequence (Lyons and Leavitt, I96I, p. 34-35) is the folding of the basement ice by the advance 
of glacial ice, probably during the time of minor glaciation along northern Ellesmere Island (Lyons and Leavitt, I961, p. I7, 34) between 3000 and I600 B.P. Whether the glacial ice in ARLIS II is equivalent in time to the possible glacial ice in the Ellesmere Island basement (Marshall, 1955, p. I12; Lyons and Leavitt, I961) or to the glacial ice which advanced to fold the inner margins of the basement is uncertain at this time. However, the former interpretation seems more likely because of the relative complexity of the banded tongue and sea-ice salient development both of which postdate the glacial ice on ARLIS II.

\section{Comparison of ARLiS II with the Ice Shelf of Ellesmere Island}

The ice shelf of Ellesmere Island (and Fletcher's Ice Island, T-3) consists of an upper layer of iced firn and interstratified lake ice overlying a basement ice of more diverse composition (Marshall, r955, p. I 10-12; 1960, p. 45-47; Crary, I958, p. 35; Lyons and Leavitt, I96I, p. 6-12; Nakaya and others, I962, p. I9-22). ARLIS II, by contrast, consists primarily of glacial and sea ice-it presently lacks the upper unit of iced firn and lake ice. It should be noted, however, that bodies of lake ice similar to those interbedded with the iced firn on $\mathrm{T}-3$ were present at two restricted localities (now destroyed) on ARLIS II, suggesting the former presence of the upper unit. In addition, the presence on ARLIS II of a very widespread, thin, surface dirt layer apparently unrelated to the debris concentrations, also suggests the former presence of an iced firn cover. It would thus appear that the ARLIS II ice is the equivalent of the ice shelf basement and that it has lost its iced firn cover by ablation.

The relations mapped on ARLIS II support Marshall's conclusion (1955, p. I i 2; i96o, p. 46-47) that glacial ice is an important part of the basement, at least locally. They also support the findings of Ragle and others (cited in Lyons and Leavitt (196r, p. 12)) that sea ice forms extensive parts of the ice shelf basement.

Finally, the possibility exists that the ARLIS II ice may not be a denuded mass of ice shelf basement, but instead a distinct and rather atypical form of shelf ice which never had an extensive iced firn cover. In this case, its involved structural history may be equivalent in time to the entire sequence of events recorded in both the upper and lower units of the Ward Hunt Ice Shelf. Discussions of the probable sequence of events in the development of the ice shelf are presented in Crary and others (1955, p. I I 71-73), Crary (1960, p. 41-46), and Lyons and Leavitt (I96I, p. 34-35).

\section{Acknowledgements}

The writer gratefully acknowledges the support and encouragement of numerous individuals with the Coastal Studies Institute, the Arctic Research Laboratory, the Geography Branch, Office of Naval Research, and on ARLIS II. In particular, he wishes to thank Dr. Max Britton who suggested the study, Prof. Richard J. Russell for granting time for the field work and preparation of results, R. Lynn Schraeder whose energetic assistance in the field was invaluable, Dr. Charles A. Knight for studying the ice samples and reading part of the manuscript, and Prof. Donald H. Kupfer for stimulating discussions of the structural problems.

Discussions in the field with A. M. Hansen, J. W. Cooper, H. Kutschale, D. J. Robinson, S. L. Den Hartog and W. T. McComas were most beneficial. Prof. John B. Lyons and Prof. Wilford F. Weeks read the manuscript. The writer's wife, Myrtle N. Smith, compiled the reference list. Marjorie Johnson drafted the figures.

MS. received io November 1962

\section{REFERENCES}

Ahnert, F. 1963. The terminal disintegration of Steensby Gletscher, north Greenland. Fournal of Glaciology, Vol. 4,

No. 35, p. $537-45$.
Allen, C. R., and others. 1960. Structure of the lower Blue Glacier, Washington, by C. R. Allen, W. B. Kamb, M. F. Meier and R. P. Sharp. Journal of Geology, Vol. 68, No. 6, p. 6o1-25. 
Barnes, D. F. 1960. An investigation of a perennially frozen lake. Bedford, Mass., Geophysics Research Directorate, U.S. Air Force Cambridge Research Laboratories. (Air Force Surveys in Geophysics, No. 1 29.)

Burkhanov, V. F. 1957. Uspekhi sovetskikh geograficheskikh issledovaniy v Arktike [Successes of Soviet explorations in the Arctic]. In Burkhanov, V. F., ed. Cherez okean ni'dreyfuyushchikh l'dakh [Across the ocean on drifting ice]. Moscow, Gosudarstvennoye Izdatel'stvo Geograficheskoy Literatury [State Publishing House for Geographical Literature], p. 3-49. [English translation published by Defence Research Board of Canada (T253R).]

Bushnell, V. C., ed. 1959-6o. Scientific studies at Fletcher's ice island, T-3, 1952-1955. Bedford, Mass., Geophysics Research Directorate, U.S. Air Force Cambridge Research Center. 3 vols. (Geophysical Research Papers, No. 63.)

Cabaniss, G. I 961 . Recent investigations on Fletcher's ice island (T-3). (In Rigsby, G. P., and Bushnell, V. C., ed. Proceedings of the third annual Arctic planning session, November 1960. Bedford, Mass., Geophysics Research Directorate, U.S. Air Force Cambridge Research Laboratories, p. 37-44. (GRD Research Notes, No. 55.))

Crary, A. P. 1956. Geophysical studies along northern Ellesmere Island. Arctic, Vol. 9, No. 3, p. 155-65.

Crary, A. P. 1958. Arctic ice island and ice shelf studies. Part I. Arctic, Vol. I I, No. 1, p. 2-42.

Crary, A. P. 1960. Arctic ice island and ice shelf studies. Part II. Arctic, Vol. 13, No. 1, p. $32-50$.

Crary, A. P., and others. I 952. Preliminary report on scientific work on "Fletcher's Ice Island", T-3, by A. P. Crary, R. D. Cotell and T. F. Sexton. Arctic, Vol. 5, No. 4, p. 2 I I-23.

Crary, A. P., and others. I 955 . Evidences of climatic change from ice island studies, by A. P. Crary, J. L. Kulp and E. W. Marshall. Science, Vol. 122, No. 3181, p. $1171-73$.

Debenham, F. 1920. A new mode of transportation by ice. Quarterly Journal of the Geological Society of London, Vol. 75 , Pt. 2, p. $5^{\mathrm{I}-76}$.

Debenham, F. [1949.] The problem of the great Ross Barrier. Geographical fournal, Vol. 1 12, Nos. 4-6, 1948, p. $196-218$.

Debenham, F. 1954. The ice islands of the Arctic: a hypothesis. Geographical Review, Vol. 44, No. 4, p. 495-507.

Dibner, V. D. 1955. O proiskhozhdenii plovuchikh ledyanykh ostrovov [On the origin of floating ice islands]. Priroda [Nature], 1955, No. 3, p. 89-92. [English translation published by Defence Research Board of Canada $\left(\mathrm{T}_{1} 76 \mathrm{R}, \mathrm{p} . \mathrm{II}-\mathrm{I} 4\right)$.]

Gould, L. M. 1935. The Ross Shelf Ice. Bulletin of the Geological Society of America, Vol. 46, No. 9, p. $1367-94$.

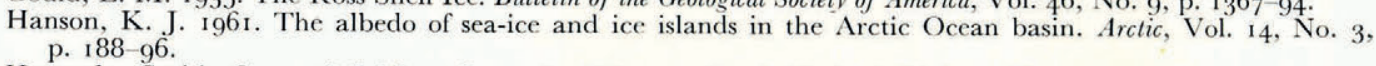

Hattersley-Smith, G. 1957[a]. The rolls on the Ellesmere ice shelf. Arctic, Vol. Io, No. I, p. 32-44.

Hattersley-Smith, G. I957[b]. The Ellesmere ice shelf and the ice islands. Canadian Geographer, No. 9, p. 65-70.

Hattersley-Smith, G. I961. Glaciology. Canadian Geophysical Bulletin, Vol. 14, p. 91-104.

Hattersley-Smith, G., and others. 1955. Northern Ellesmere Island, I953 and 1954, by G. Hattersley-Smith, A.P. Crary and R. L. Christie. Arctic, Vol. 8, No. 1, p. 2-36.

Helk, J. V., and Dunbar, Moira. 1953. Ice islands: evidence from north Greenland. Arclic, Vol. 6, No. 4, p. $263-7$ 1.

Kamb, W. B. 1959. Ice petrofabric observations from Blue Glacier, Washington, in relation to theory and experiment. Journal of Geophysical Research, Vol. 64, No. 11, p. 1891-19o9.

Knight, C. A. 1962. Polygonization of aged sea ice. Journal of Geology, Vol. 7o, No. 2, p. $240-46$.

Koenig, L. S., and others. I952. Arctic ice islands, by L. S. Koenig, K. R. Greenaway, Moira Dunbar and G. Hattersley-Smith. Arctic, Vol. 5, No. 2, p. 67-103.

Kutschale, H. Unpublished. Arctic Basin acoustic studies. [Unpublished progress report, U.S. Arctic Research Laboratory, August r961.]

LeShack, L. A. I961. ARLIS II: new Arctic drift station. Naval Research Reviews, September 1961, p. 12-18.

Lyons, J. B., and Leavitt, F. G. 1961. Structural-stratigraphic studies on the Ward Hunt Ice Shelf. Bedford, Mass., Geophysics Research Directorate, U.S. Air Force Cambridge Research Laboratories. (Final Report, Contract $\mathrm{AF}_{19}$ (604)-6 188 , AFCRL-442.)

Macdonald, W. J. P., and Hatherton, T. I961. Movement of the Ross Ice Shelf near Scott Base. Fournal of Glaciology, Vol. 3, No. 29, p. 859-66.

Marshall, E. W. 1955. Structural and stratigraphic studies of the northern Ellesmere ice shelf. Arctic, Vol. 8, No. 2, p. $109^{-1} 4$.

Marshall, E. W. 1960. Structure and stratigraphy of $\mathrm{T}-3$ and the Ellesmere ice shelf. (In Bushnell, V. C., ed. Scientific studies at Fletcher's ice island, T-3, 1952-1955. Bedford, Mass., Geophysics Research Directorate, U.S. Air Force Cambridge Research Center, Vol. 3, p. 45-57. (Geophysical Research Papers, No. 63.))

Meier, M. F. 1960. Mode of flow of Saskatchewan Glacier, Alberta, Canada. U.S. Geological Survey. Professional Paper $35^{1}$.

Montgomery, M. R. 1952. Further notes on ice islands in the Canadian Arctic. Arctic, Vol. 5, No. 3, p. $183-87$.

Nakaya, U., and Muguruma, J. 1962. Physical properties of the ice of Fletcher's ice island (T-3). Arctic Institute of North America. Research Paper No. 20. (U.S. Air Force Cambridge Research Laboratories 62-463, Scientific
Report No. 2.)

Nakaya, U., and others. 1962. Glaciological studies on Fletcher's ice island (T-3), by U. Nakaya, J. Muguruma and K. Higuchi. Arctic Institute of North America. Research Paper No. 21. (U.S. Air Force Cambridge Research Laboratories 62-464, Scientific Report No. 3.)

Nichols, R. L. [1953.] Geomorphology of Marguerite Bay, Palmer Peninsula, Antarctica. Washington, D.C., Office of Naval Research. (Ronne Antarctic Research Expedition. Technical Report No. 12.)

Poulter, T. C. 1947. Seismic measurements on the Ross Shelf Ice. Part 1. Transactions of the American Geophysical Union, Vol. 28, No. 2, p. $162-70$.

Poulter, T. C. [1 950.$]$ Geophysical studies in the Antarctic. Stanford, California, Stanford Research Institute.

[Roscoe, J. H.] 1953. Antarctica: regional photo interpretation series. [Washington, D.C., U.S.] Department of the Air Force. (Air Force Manual 200-30. Intelligence.) 
Schwarzacher, W. 1959. Pack-ice studies in the Arctic Ocean. Fournal of Geophysical Research, Vol. 64, No. 12, p. $2357-67$.

Sharp, R. P. 1947. The Wolf Creek glaciers, St. Elias Range, Yukon Territory. Geographical Review, Vol. 37. No. I, p. $26-52$.

Sharp, R. P. 1960. Glaciers. Eugene, Oregon, University of Oregon Press.

Siple, P. A. 1945. Geographical exploration from Little America III, the west base of the United States Antarctic Service Expedition, 1939-1941. Proceedings of the American Philosophical Society, Vol. 89, No. 1, p. 23-6o.

Smith, D. D. 1960. Development of surface morphology on Fletcher's ice island, T-3. Bedford, Mass., Geophysics Research Directorate, U.S. Air Force Cambridge Research Center. (Scientific Report No. 4, Contract AF 19 (604)-2 I 59, AFCRC-TN-6o-437.)

Swithinbank, C. W. M., and others. I 961 . Faunal remains on an Antarctic ice shelf, by C. W. M. Swithinbank, D. G. Darby and D. E. Wohlschlag. Science, Vol. 133, No. 3455, p. 764-66.

Taylor, L. D., and Lyons, J. B. I959. Ice structures, Angiussaq Lake, northwest Greenland. Bedford, Mass., Geophysics Research Directorate, U.S. Air Force Cambridge Research Center. (Scientific Report No. I, Contract $\mathrm{AF}_{19}(604)-2159$, AFCRC-TN-59-461.)

Untersteiner, N. 1954. Über die Feinbänderung und Bewegung des Gletschereises. Archiv für Meteorologie, Geophysik und Bioklimatologie, Ser. A, Bd. 7, p. $23 \mathrm{I}-42$.

Untersteiner, N. 1955. Some observations on the banding of glacier ice. Fournal of Glaciology, Vol. 2, No. 17, p. 502-06.

Wright, C. S., and Priestley, R. E. 1922. Glaciology. London, Harrison. (British (Terra Nova) Antarctic Expedition, 1910-1913.)

Zubov, N. N. I 955 . Arkticheskiye ledyanyye ostrova i kharakter ikh dreyfa [Arctic ice islands and the character of their drift]. Priroda [Nature], 1955, No. 2, p. 37-45. [English translation published by Defence Research Board of Canada $\left(\mathrm{T}_{1} 76 \mathrm{R}, \mathrm{p} . \mathrm{i}-\mathrm{IO}\right)$.]

Zumberge, J. H. 1958. Ross Ice Shelf deformation project, 1957-58. Transactions. American Geophysical Union, Vol. 39, No. 4, p. 794-99.

Zumberge, J. H. 1960. Geologic structures of the Ross Ice Shelf, Antarctica. Report of the International Geological Congress, XXI Session, Norden, 1960 , Pt. 21, p. 6o-67. 